\section{Interactions of the sulfur, iron, and phosphorus cycles control phosphorus sequestration in estuarine sediments}

\author{
THOMAS E JORDAN ${ }^{1}$, JEANNE L HARTZELL ${ }^{2}$ AND \\ JEFFREY C CORNWELL ${ }^{3}$ \\ ${ }^{1}$ Smithsonian Environmental Research Center \\ ${ }^{2}$ George Mason University \\ ${ }^{3}$ University of Maryland Center for Environmental Science \\ Presenting Author: jordanth@si.edu
}

Interactions of the sulfur, iron $(\mathrm{Fe})$, and phosphorus $(\mathrm{P})$ cycles may be parts of global feedback loops that control $\mathrm{P}$ availability in the sea through linkages of primary productivity, atmospheric carbon dioxide, global temperature, sea level, and the sequestration or release of $\mathrm{P}$ from estuarine sediments. We investigated these interactions by measuring particulate $\mathrm{P}$ (PP) fractions and sequestration across estuarine salinity gradients. A sequential extraction technique was used to compare the forms and amounts of PP deposited in the top meter of sediment spanning salinities from 0-11 psu in four Chesapeake Bay subestuaries: the Potomac, Patuxent, Choptank, and Bush Rivers. Fe-bound P (i.e., citrate-bicarbonate-dithionite (CDB) extractable $\mathrm{P})$ was the most dynamic fraction of $\mathrm{PP}$, dominating oligohaline sediments (salinities $<3 \mathrm{psu}$ ), but declining to near zero with depth in the most saline sediments except in the Patuxent. Particulate organic $\mathrm{P}$ was relatively constant with depth and salinity and became the dominant form of PP in the most saline sediments of all sub-estuaries, except the Patuxent. Fe-P was not replaced with diagenetic authigenic carbonate fluorapatite. Fe-P generally persisted in the oligohaline sediments to $1 \mathrm{~m}$ depth, where sediment ages ranged from $60-200$ years, based on ${ }^{210} \mathrm{~Pb}$ dating. Although the $\mathrm{CDB}$ extraction targets iron oxides, the predominant form of $\mathrm{Fe}$ in the sediments was ferrous, suggesting that the predominant form of PP in oligohaline sediments may be ferrous phosphate. As salinity increased above $3 \mathrm{psu}$, the pore water dissolved Fe:phosphate ratio decreased below 2, while the dissolved inorganic N:P ratio shifted from $>16$ to $<16$. This suggests that increasing salinities above 3 psu may supply enough sulfide to bind with the ferrous $\mathrm{Fe}$ in these sediments, thereby releasing dissolved phosphate from ferrous phosphate and changing the dissolved inorganic $\mathrm{N}: \mathrm{P}$ ratio enough to promote a change in phytoplankton limitation from $\mathrm{P}$ to $\mathrm{N}$. Future Increases in global temperature and sea level may lead to increases in estuarine salinity and decreases in dissolved oxygen that could stimulate phosphate release and primary productivity.

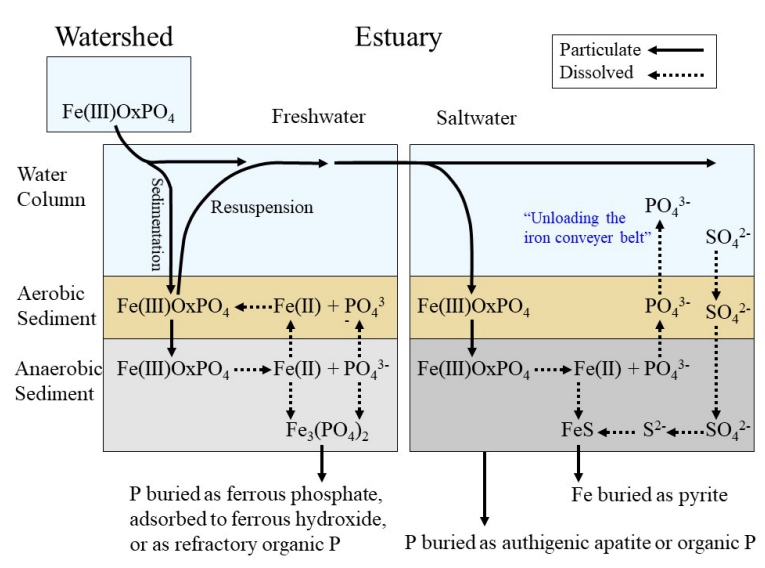

